\title{
PENGARUH PENYULUHAN TERHADAP PENINGKATAN PERILAKU PENGGUNAAN ALAT PELINDUNG DIRI
}

\author{
Riski Dani Simanjuntak, Solichin, Erianto Fanani \\ Fakultas Ilmu Keolahragaan Universitas Negeri Malang
}

\begin{abstract}
Manual Plastic Injection Machine is a tool used to mold the plastics powder to the plastics product. The working process may cause accidents and harm the workers, this supported by interview and observation which held at the preliminary survey that there was accidents but only one of 13 workers who used PPE.Due to these reason, counseling intervention is an effort to improve PPE usage behavior.The aim of this study is to know the effect of counseling to PPE usage behavior to the workers and the method is observational cross sectional. This studied used one group pretes posttest design to 13 workers which is working with injection machine and on the day shift. Data accumulated with test form instrument for knowledge aspect, questionnaire form for attitude aspect and observation method for act aspect. Hypothesis test was conducted by using Wilcoxon Test.The result showed knowledge mean score before counseling 6,08 and after counseling score 9,00. Based on Wilcoxon test was acquired p score 0,002<0,05. Attitude aspect mean score that was acquired before counseling 27 and after counseling 28,85 which the Wilcoxon test showed p score 0,049<0,05.Mean score was acquired by observation before counseling 0,08 and after conseling mean score was acquired 2,53 by three times observation.The conclusion is, that there is difference in PPE usage behavior of CV. Rangros Plastik workers by counselling.
\end{abstract}

\section{Keywords:counselling, PPE, behavior}

\begin{abstract}
Abstrak:Mesin injeksi plastik manual merupakan alat yang digunakan dalam mencetak plastik dari butiran menjadi produk plastik. Proses pekerjaan pencetakan plastik memiliki risiko kecelakaandan mengganggu kesehatan pekerja,didukung dari hasil wawancara bahwa pernah terjadi kecelakaan kerja. Pekerja tidak menggunakan APD saat bekerja merupakan salah satu perilaku tidak aman karena berisiko kecelakaan. Survey pendahuluan menunjukan hanya satu dari sembilan pekerja yang mengenakan sarung tangan, sehingga penyuluhan dilakukan sebagai upaya meningkatkan perilaku penggunaan APD pekerja.Penelitian ini bertujuan mengetahui pengaruh penyuluhan terhadap peningkatan perilaku penggunaan APD. Penelitian dilakukan dengan metode observational cross sectional dengan desainone group pretest posttest pada 13 pekerja dengan karakteristik pekerja menggunakan mesin injeksi dan bekerja pada waktu pagi. Pengumpulan data menggunakan instrumen berupa tes untuk aspek pengetahuan, kuesioner pada aspek sikap dan observasi untuk melihat tindakan. Uji hipotesis dilakukan menggunakan uji Wilcoxon.Hasil yang didapatkan menunjukan rata-rata pengetahuan pekerja sebelum penyuluhan 6,08 dan setelahnya 9,00 yang berarti ada peningkatan rata-rata pengetahuan. UjiWilcoxon diperoleh skor p 0,002<0,05 yang berarti terdapat perbedaan pengetahuan setelah adanya penyuluhan. Rata-rata sikap sebelum penyuluhan 27 dan setelahnya 28,85 yang berarti terdapat peningkatan sikap, uji Wilcoxon diperoleh skor p 0,049<0,05 yang berarti terdapat perbedaan sikap setelah adanya penyuluhan. Rata-rata tindakan pekerja dari observasi sebelum penyuluhan 0,08 dan setelah tiga kali observasi diperoleh 2,53 yang berarti terdapat perbedaan tindakan pekerja dalam menggunakan APD.Kesimpulannya adalah terdapat perbedaan perilaku penggunaan APD pada pekerja di CV. Rangros Plastik setelah adanya penyuluhan.
\end{abstract}

Kata Kunci: penyuluhan, APD, perilaku

\section{PENDAHULUAN}

Kebutuhan akan penggunaan produk yang diproduksi dari bahan plastik dalam rumah tangga dapat dipastikan sangat besar, seperti sendok, piring, cetakan kue dan lainya. Pembuatan benda-benda dari plastik tersebut tidak lepas dari penggunaan alat atau mesin, dimana mesin ini dapat mencetak material plastik menjadi

bentuk plastik sesuai dengan cetakan.Proses pencetakan plastikdengan menggunakan mesin injeksi ini berdasarkan Rees (2002, 
dalam Gunaraharja, 2015) yaitu diawali dari termoplastik (bahan plastik yang mudah berubah karena suhu) dalam bentuk butiran atau bubuk yang ditampung dalam sebuah hopper atau corong, butiran atau bubuk plastik akan dilelehkan oleh pemanas yang terdapat di dinding barrel dan oleh gesekan akibat perputaran sekrup injeksi. Plastik yang sudah meleleh diinjeksi oleh sekrup injeksi (yang juga berfungsi sebagai plunger atau pendorong) melalui nozzle (corong penyemprot) ke dalam cetakan yang diinginkan, dan kemudian didinginkan oleh air untuk memadatkan kembali.

Salah satu perusahaan yang bergerak dalam usaha pengelolahan material plastik menjadi produk plastik yang ada di Kota Malang adalah CV. Rangros Plastik. Produksi yang

dilakukan pada perusahaan ini menggunakan mesin injeksi manual dimana setiap mesin di operasikan oleh satu orang pekerja.Penelitian pendahuluan yang dilakukan oleh peneliti dengan metode observasi dan wawancara pada tanggal 6 September 2016 di perusahaan tersebut, dapat diketahui terdapat sembilan orang pekerja pada bagian pencetakan plastik yang menggunakan mesin injeksi manual ini. Sementara itu berdasarkan dari identifikasi risiko yang dilakukan peneliti diketahui bahwa proses pekerjaan pencetakan plastik dengan mesin injeksi manual seperti ini memiliki risiko untuk terjadi kecelakaan kerja dan mengganggu kesehatan pekerja, dimana didukung dari hasil wawancara di lapangan dengan pemilik usaha dan pekerja yang mengatakan bahwa pernah terjadi kecelakaan kerja yang menimpa pekerja pada bagian pencetakan plastik yang menggunakan mesin injeksi manual. Kecelakaan kerja yang terjadi seperti kaki tertimpa besi sehingga menyebabkan jari pekerja harus diamputasi, tangan terjepit mesin ketika mengeluarkan hasil cetakan dimana pekerja lalai untuk mendorong tungkai secara maksimal sehingga akhirnya tungkai kembali keposisi menjempit serta kepala tertimpa tungkai.

Menurut Silalahi (1995 dalam Annishia, 2011), unsafe act adalah setiap perbuatan atau kondisi tidak selamat yang dapat mengakibatkan kecelakaan. Berdasarkan statistik di Indonesia, $80 \%$ kecelakaan diakibatkan oleh tindakan tidak aman (unsafe act) dan 20\% disebabkan oleh kondisi tidak aman (unsafe condition). Fakta di lapangan menunjukkan hanya satu dari sembilan pekerja yang mengenakan sarung tangan sebagaiAlat Pelindung Diri(APD) dan tidak ditemukan pekerja yang mengenakan APD lainnya seperti sepatu safety dan masker yang mana pekerja yang tidak menggunakan APD saat bekerja merupakan salah satu bentuk perilaku yang tidak aman.

Menurut Notoatmodjo (2010), upaya intervensi terhadap faktor perilaku dapat dilakukan melalui dua pendekatan, yaitu pendidikan atau

paksaan/tekanan, dan pendekatan pendidikan adalah yang paling tepat sebagai upaya untuk memecahkan masalah kesehatan masyarakat melalui faktor perilaku. Salah satu upaya dalam bentuk pendidikan kesehatan yang memungkinkan untuk merubah perilaku adalah dengan penyuluhan. Menurut

(Azwar, 1983 dalam Maulana, 2009),penyuluhan kesehatan diartikan sebagai kegiatan pendidikan kesehatan yang dilakukan dengan cara menyebarluaskan pesan dan menanamkan keyakinan, sehingga pada akhirnya sasaran yang diinginkan tidak hanya sadar, tahu, dan mengerti, tetapi juga mau dan dapat melakukannya Berdasarkan penjelasan tersebut maka peneliti bermaksud untuk mengetahui pengaruh penyuluhan terhadap peningkatan perilaku penggunaan APD pada pekerja di CV. Rangros Plastik Sawajojar Kota Malang.

Menurut Solichin (2014), Alat Pelindung Diri (APD) adalah alat yang digunakan untuk membuat rintangan secara efektif antara orang dan benda berbahaya, bahan dan radiasi serta merupakan upaya terakhir pengendalian 
bahaya Menurut.OSHA (Occupational Safety and Health Administration), (2005) Alat Pelindung Diri, atau biasa disingkat APD adalah suatu alat untuk meminimalisir terjadinya luka dari kontak dengan berbagai macam bahaya. Contoh dari APD termasuk sarung tangan, pelindung kaki dan mata, pelindung alat pendengaran, helm, respirator dan pakaian pelindung.

Perilaku adalah semua kegiatan atau aktifitas manusia baik yang dapat diamati langsung maupun tidak dapat diamati oleh pihak luar. Perilaku manusia pada hakikatnya tindakan manusia itu sendiri yang bentanganya sangat luas (Fitriani, 2011). Berdasarkan segi psikologi, perilaku menurut Skiner yang dikutip oleh Maulana (2009) adalah respons seseorang terhadap stimulus yang diberikan. Benyamin Bloom (1908, dalam Notoatmodjo,2010) membedakan adanya tiga ranah atau area atau domain perilaku untuk kepentingan pendidikan praktis, yaitu pengetahuan, sikap dan tindakan.

Menurut Notoatmodjo (2010) pengetahuan merupakan hasil dari penginderaan manusia, atau hasil tahu seseorang dengan objek melalui indera yang dimiliki manusia.Sementara itumenurut Koetjaningrat(1983, dalam Maulana, 2009) sikap merupakan kecenderungan yang berasal dari dalam diri individu untuk untuk berkelakuan denga pola-pola tertentu, terhadap suatu objek akibat pendirian dan perasaan terhadap objek tersebut. Menurut Allport dalam Azwar (2013) sikap adalah semacam kesiapan untuk bereaksi terhadap suatu objek dengan cara-cara tertentu.Menurut Maulana (2009), sikap tidak secara otomatis terwujud dalam suatu tindakan (overt behavior). Untuk mewujudkan sikap menjadi tindakan, diperlukan faktor

pendukung atau kondisi yang memungkinkan, antara fasilitas dan dukungan.Berdasakan teori Lawrence Green yang dikutip Notoatmodjo (2010) bahwa faktor perilaku sendiri di tentukan oleh tiga faktor utama, pertama faktor predisposisi yaitu faktor yang mempermudah atau mempredisposisi terjadinya perilaku seseorang, antara lain pengetahuan, sikap, keyakinan, kepercayaan, nilai-nilai, tradisi, dn sebagaianya. Kedua adalah faktor

pemungkin yaitu faktor yang memungkinkan atau memfasilitasi perilaku atau tindakan dan yang ketiga adalah faktor penguat yaitu faktor yang mendorong atau memperkuat terjadinya perilaku.

Machfoedz dkk(2005, dalam Maulana, 2009) menyebutkan bahwa penyuluhan adalah sebagai hubungan timbal balik antara dua orang individu (penyuluh dan klien) untuk mencapai pengertian tentang diri sendiri dalam hubungan dengan masalah-masalah yang dihadapi pada waktu yang akan datang.Samsudin(1977, dalam Suprapto dan Fahrianoor , 2004) menyebutkanfungsi penyuluhan adalah sebagai penghubung yang menjabarkan proses penyampaian ilmu dan teknologi dari sumbernya kepada masyarakat yang membutuhkanya Penyuluhan tidak dapat lepas dari media karena melalui media pesan disampaikan dengan mudah untuk dipahami. Media promosi kesehatan dapat dikelompokan menjadi media cetak,media elektronik dan media luar ruangan (Notoatmodjo, 2010).

\section{METODE}

Penelitian yang dilakukan adalah observational cross sectional. Penelitian ini menggunakan desain penelitian one group pretest posttest dan hanya menggunakan satu kelompok.Sebelum melaksanakan penyuluhan, peneliti memberikan tes terkait pengetahuan dan sikap subjek pada penggunaan APD ketika bekerja sebagai pretest kepada pekerja yang

kemudian penyuluh melakukan penyuluhan.Kemudian subjek diberikan kuesioner sebagai posttest untuk melihat peningkatan pengetahuan dan perbaikan sikap. Posttest untuk melihat perubahan tindakan dengancara observasi dilakukan tiga kali selama satu minggu setelah penyuluhan. Pengumpulan data dalam penelitian ini menggunakan data 
primer yang diperoleh melalui instrumen

tes untuk memperoleh gambaran pengetahuan dan kuesioner untuk memperoleh gambaran sikapresponden terkait penggunaan APD serta observasi langsung untuk melihat tindakan responden terkait penggunaan APD. Data yang diperoleh akan diuji dengan uji Wilcoxon untuk melihat perbedaan aspek pengetahuan dan sikap sementara pada aspek tindakan dengan membandingkan nilai rata-rata.

\section{HASIL}

Gambaran Pengetahuan

Tabel 1.Perbedaan Tingkat Pengetahuan Pekerja Sebelum Dan Setelah Penyuluhan

\begin{tabular}{ccccc}
\hline \multirow{2}{*}{ Tingkat Pengetahuan } & \multicolumn{3}{c}{ Pretest } & \multicolumn{2}{c}{ Posttest } \\
\cline { 2 - 5 } & $\mathbf{f}$ & \% & f & \% \\
\hline Baik & 1 & 7,7 & 5 & 38,5 \\
Cukup & 6 & 46,1 & 6 & 46,1 \\
Kurang & 6 & 46,1 & 2 & 15,4 \\
Total & 13 & 100 & 13 & 100 \\
\hline
\end{tabular}

$\begin{array}{lll}\text { Berdasarkan tabel } 1 \text { diketahui } & \text { memiliki pengetahuan yang baik pada } \\ \text { bahwa responden yang } & \text { memiliki } & \begin{array}{l}\text { postest menjadi lima responden }(38,5 \%) \\ \text { dari seluruh responden. }\end{array} \\ \text { pengetahuan baik hanya satu pada saat } & \end{array}$

Tabel 2. Perubahan Pengetahuan

\begin{tabular}{ccc}
\hline Perubahan Pengetahuan & Jumlah & Persentase \\
\hline Menurun & 0 & $0 \%$ \\
Tetap & 1 & $7,7 \%$ \\
Meningkat & 12 & $92,3 \%$ \\
Total & 13 & $100 \%$ \\
\hline \multirow{2}{*}{ Berdasarkan tabel } & 2 dapat & pengetahuan dengan jumlah responden \\
diketahui bahwa terdapat penerja $(92,3 \%)$ & dari seluruh \\
& responden pengetahuannya meningkat.
\end{tabular}


Gambaran Sikap

Tabel 3. Perbedaan Sikap Pekerja Sebelum Dan Setelah Penyuluhan

\begin{tabular}{ccccc}
\hline \multirow{2}{*}{ Sikap } & \multicolumn{2}{c}{ Pretest } & \multicolumn{2}{c}{ Posttest } \\
\cline { 2 - 5 } & $\mathbf{f}$ & $\mathbf{\%}$ & $\mathbf{F}$ & $\mathbf{\%}$ \\
\hline Baik & 3 & $23,1 \%$ & 4 & $30,8 \%$ \\
Cukup & 8 & $61,5 \%$ & 8 & $61,5 \%$ \\
Buruk & 2 & $15,4 \%$ & 1 & $7,7 \%$ \\
Total & 13 & 100 & 13 & 100 \\
\hline
\end{tabular}

Berdasarkan tabel 3 diketahui terdapat tiga responden $(23,1 \%)$ yang memiliki sikap yang baik dari seluruh responden pada saat pretest. Sementara padaposttest diketahuiresponden yang sikapnya baik menjadi empat pekerja $(30,8 \%)$ dari seluruh responden.

Tabel 4. Perubahan Sikap

\begin{tabular}{ccc}
\hline Perubahan Sikap & Jumlah & Persentase \\
\hline Menurun & 3 & $23,1 \%$ \\
\hline Tetap & 1 & $7,7 \%$ \\
\hline Meningkat & 9 & $69,2 \%$ \\
\hline Total & 13 & $100 \%$
\end{tabular}

Berdasarkan tabel 4 dapat diketahui bahwa terdapat peningkatan, dengan jumlah responden yang sikapnya meningkat sebesar sembilan responden $(69,2 \%)$.

\section{Gambaran Tindakan}

Tabel 5. Perubahan Tindakan

\begin{tabular}{|c|c|c|c|c|c|c|c|}
\hline \multirow{2}{*}{\multicolumn{2}{|c|}{ responden }} & \multicolumn{6}{|c|}{ APD } \\
\hline & & \multicolumn{2}{|c|}{ Sarung Tangan } & \multicolumn{2}{|c|}{ Masker } & \multicolumn{2}{|c|}{ Helm } \\
\hline & & f & $\%$ & $\mathbf{f}$ & $\%$ & $\mathbf{f}$ & $\%$ \\
\hline Pre & 12 & 1 & 7,7 & 0 & 0 & 0 & 0 \\
\hline Post 1 & 10 & 9 & 90 & 2 & 20 & 0 & 0 \\
\hline Post 2 & 12 & 12 & 100 & 2 & 16,6 & 0 & 0 \\
\hline Post 3 & 10 & 8 & 80 & 0 & 0 & 0 & 0 \\
\hline
\end{tabular}

Tabel 5 menunjukan pada saat pretest hanya terdapat satu responden $(7,7 \%)$ yang menggunakan sarung tangan, dan tidak ditemukan yang menggunakan masker dan helm. Tabel 5 jugamenunjukan terdapat peningkatan paling tinggi terjadi pada posttest kedua dimana diketahui 12 responden (100\%) dari seluruh pekerja yang datang bekerja menggunakan sarung tangan ketika bekerja dan dua responden $(16,6 \%)$ yang menggunakan masker ketika bekerja.

\section{Pengaruh Penyuluhan Terhadap Peningkatan Perilaku}

Hipotesis penelitian yang digunakan adalah " adaperbedaan perilaku penggunaan APD pada pekerja di CV. Rangros Plastik, Kota Malang setelah diberikan penyuluhan". Mengetahui perbedaan perilaku yang diintrepetasikan dalam tiga aspek yaitu pengetahuan, sikap dan tindakan, dengan melihat perbedaan skor antara pretest dan postest. Analisis perbedaan yang terjadi dilakukan dengan menggunakan uji Wilcoxon. Perubahan 
aspek pengetahuan dan sikap digambarkan dalam tabel 6

Tabel 6.Hasil Uji Wilcoxon Aspek Pengetahuan dan Sikap

\begin{tabular}{lcccc}
\hline \multicolumn{1}{c}{ Aspek } & Penilaian & N & Rata-Rata & PValue \\
\hline \multirow{2}{*}{ Pengetahuan } & Pretest & 13 & 6,08 & \multirow{2}{*}{0,002} \\
\cline { 2 - 5 } Sikap & Posttest & 13 & 9,00 & \\
\hline \multirow{2}{*}{ Pretest } & 13 & 27 & \\
\cline { 2 - 5 } & Posttest & 13 & \multicolumn{2}{c}{$28,850,049$} \\
\hline
\end{tabular}

Pada aspek pengetahuan pekerja pencetakan plastik memiliki nilai ratarata pada saat pretest sebesar 6,08 dan pada saat posttest dengannilai 9,00 yang mana berarti terjadi perubahan atau perbedaan. Uji statistik Wilcoxon pada pengetahuan didapatkan $p$ value $=0,002$ $<0,05$ (alpha 5\%) yang berarti $\mathrm{H} 1$ diterima, yang berarti terdapat perbedaan yang signifikan pada aspek pengetahuan setelah penyuluhan.

Pada aspek sikap pekerja, nilai

rata-rata yang didapat saat pretest sebesar 27 dan saat postest bernilai 28,85 yang berarti ada perubahan atau perbedaan nilai rata-rata sebesar 1,85 . Uji statistik Wilcoxon didapatkan $p$ value $=0,049<0,05$ (alpha 5\%) sehingga H1 diterima, yang berarti terdapat perbedaan sikap yang signifikan pada pekerja setelah penyuluhan. Sementara itu perubahan dalam tindakan dapat dilihat dari tabel 7 berikut.

Tabel 7Perbandingan Nilai Rata-RataPretest denganPosttest Total

\begin{tabular}{cc}
\hline Penilaian & Rata-Rata \\
\hline Rata-Rata Pretest & 0,08 \\
Rata-Rata Posttest total & 2,53 \\
\hline
\end{tabular}

Tabel 7 menunjukan adanya perbedaan nilai rata-rata tindakan penggunaan APD sebelum penyuluhan sbesar 0,08 dengan nilai rata-rata total setelah diadakanya penyuluhan yang didapatkan dari penjumlahan seluruh skor rata-rata setiap posttest dan dibagi tiga sebesar 2,53. Sehingga terjadi perubahan rata-rata pengguna APD sebesar 2,45 maka H1 diterima, yang berarti terdapat peningkatan tindakan penggunaan APD setelah penyuluhan.

Berdasarkan perubahan peningkatan yang didapatkan dari hasil skoring pada ketiga aspek, maka H1 penelitian ini diterima. Berarti terdapat pengaruh penyuluhan terhadap peningkatan perilaku penggunaan APD pada pekerja CV. Rangros Plastik Kota Malang.

\section{PEMBAHASAN}

Pengetahuan Pekerja Sebelum dan Setelah Penyuluhan

Perilaku dapat dibentuk dengan pemberian pengertian yaitu dengan belajar secara kognitif. (Fitriani, 2011). Menurut Bandura dalam Santrock (2008) dari faktor kognitif individu dan lingkungan dapat mempengaruhi perilaku. Membentuk perilaku bekerja dengan menggunakan APD pada pekerja pencetakan plastik mesin injeksi manual dapat dilakukan dengan penyampaian informasi antara lain dengan memberikan penyuluhan di bidang Keselamatan dan Kesehatan Kerja (K3) tentang APD.

Pengetahuan pekerja didapatkan dari tes yang diberikan pada responden sebelum dilakukan penyuluhan, dan diketahui bahwa yang memiliki pengetahuan baik hanya satu responden dan enam responden berpengetahuan cukup serta enam sisanya 
berpengetahuan kurang. Pengetahuan yang kurang dan cukup merupakan faktor yang menyebabkan sesorang tidak dapat berperilaku yang baik. Berdasarkan teori Lawrence Green dalam Notoatmodjo (2010) yang mengatakan bahwa ada tiga faktor yang menentukan perilaku, salah satu faktornya adalah faktor predisposisi. Pada predisposisi ini antara lain yaitu pengetahuan sebagai pembentuk utama dalam menentukan perilaku seseorang. Sehingga dengan pengetahuan kurang mengenai K3, APD serta bahaya ketika bekerja dapat menentukan pekerja untuk mau berperilaku selamat ketika bekerja.

Sehingga diadakan pendidikan kesehatan berupa penyuluhan dengan materi mengenai Fungsi APD dan bahaya tidak menggunakan APD. Sesuai dengan yang disampaikan Bandura dalam Santrock (2008) bahwa tingkat

kognitif sesorang mempengaruhi perilaku, dimana penyuluhan menurut Notoatmodjo (2010) merupakan salah satu bentuk pendidikan kesehatan, oleh karena itu penyuluhan disampaikan kepada pekerja untuk mempengaruhi kognitif pekerja.

Rata-rata pengetahuan pekerja mengenai bahaya tidak menggunakan APD dan Fungsi APD saat pretest bernilai 6,08 dan setelah diberikan penyuluhan mengalami peningkatan 2,92 dimana nilai rata-rata posttestnya 9,00 . Peningkatan nilai rata-rata tersebut menunjukan adanya peningkatan pengetahuan pekerja dari sebelum hingga setelah adanya penyuluhan.

Penyuluhan ini juga terbukti berpengaruh dengan meningkatnya jumlah responden yang berpengetahuan baik. Peningkatan pengetahuan ini juga diketahui dari hasil uji statistik Wilcoxon dengan hasil $p$ value yaitu sebesar 0,002 . Pada alpha $5 \%$ hasil $p$ value memiliki arti terdapat perbedaan yang signifikan pada pengetahuan pekerja pencetakan plastik.

Penelitian yang dilakukan oleh Mostafa dan Momen (2014) pada siswa pendidikan teknik di Abbasia, Kairo juga memiliki hasil yang sama. Setelah diberikannya program pendidikan kesehatan secara statistik terdapat peningkatan yang signifikan terhadap pengetahuan dari hukum bekerja dengan $p$ value 0,004 , manajemen yang sesuai tumpahan bahan kimia dengan $p$ value

0,035 dan pengetahuan bahaya kebisingan mesin 0,05. Dapat diartikan kesimpulannya ada pengaruh pendidikan kesehatan terhadap pengetahuan siswa

Hasil serupa juga didapatkan dalam penelitian yang dilakukan oleh Hameed dkk tahun 2012 pada industri tekstil di Behara. Ditemukan perbedaan dalam peningkatan secara signifikan dalam pengetahuan pekerja dalam gangguan sistem pernapasan dan ketulian dengan nilai signifikasi yang bermakna, $(\mathrm{P}<0.0001)$ setelah adanya pendidikan. Kesimpulannya adalah intervensi pendidikan efektif dan berhasil menunjukan peningkatan dalam pengetahuan pekerja dan penggunaan APD dari sebelum diberikan intervensi.

Penelitian pengaruh penyuluhan yang dilakukan oleh Pratama (2013) menunjukan hasil perhitungan pengujian Paired sample test pada pengetahuan memperlihatkan $t$-test $=-9.543$ dengan nilai $p$-value $=0,001$. Hasil tersebut dapat disimpulkan ada pengaruh pendidikan terhadap perubahan nilai pengetahuan responden tentang kebiasaan berperilaku hidup bersih dan sehat antara pretest dan posttest.

\section{Sikap Pekerja Sebelum dan Setelah Penyuluhan}

Sama halnya dengan

pengetahuan, sikap merupakan salah satu ranah/domain dalam membentuk suatu perilaku. Sikap juga termasuk dalam faktor predisposisi sebagai pembentuk seseorang untuk mau berperilaku (Notoatmodjo, 2010).

Hasil pretest yang didapatkan dari kusioner menunjukan bahwa hanya tiga responden $(23,1 \%)$ yang memiliki sikap yang baik mengenai bahaya tidak menggunakan APD dan fungsi dari APD dari seluruh responden, delapan responden $(61,5 \%)$ memiliki sikap kategori cukup dan dua responden 
sikapnya $(15,4 \%)$ dalam kategori yang buruk dari seluruh responden. Dari hasil ini diketahui bahwa sebagian besar subjek memiliki sikap dalam kategori cukup, namun dalam hal menggunakan APD dapat dikatakan mayoritas pekerja belum ada yang menggunakan APD. Allport (1954, dalam Notoatmodjo, (2012) menyebutkan bahwa sikap itu

mempunyai tiga komponen yaitu kepercayaan, kehidupan emosional dan kecenderungan untuk bertindak namun kondisi pekerja saat pretest masih belum memenuhi komponen sikap tersebut, dapat dilihat dari mayoritas pekerja yang kecenderungannya bekerja tidak menggunakan APD dimana dalam proses kerja tersebut memiliki potensi bahaya penyakit akibat kerja ataupun

risiko kecelakaan akibat kerja. Penyuluhan disampaikan juga sebagai suatu stimulus untuk mendapatkan respon perilaku yang yang baik dalam

penggunaan APD pada pekerja pencetakan plastik. Sesuai dengan yang dikutip dalam Notoatmodjo (2012) sikap adalah penilaian sesorang terhadap stimulus yang diberikan, dan dimana selanjutnya setelah stimulus maka sesorang akan bersikap. Penyampaian materi bahaya tidak menggunakan APD dan fungsi APD merupakan upaya untuk merubah pendapat dalam hal ini sikap pekerja terhadap penggunaan APD.

Skor posttest sikap yang didapatkan setelah penyuluhan diketahui bahwa yang memiliki sikap yang baik sebanyak empat responden $(30,8 \%)$ dari seluruh responden, dan delapan responden $(61,5 \%)$ memiliki sikap yang cukup dari seluruh responden serta yang bersikap buruk hanya satu responden

$(7,7 \%)$ dari seluruh responden. Perubahan sikap ini dapat diketahui dengan melihat nilai rata-rata sikap pekerja saat pretest sebesar 27 dan ratarata skor sikap yang didapatkan setelah penyuluhan atau posttest yaitu sebesar 28,85 .

Penyuluhan juga diketahui berpengaruh terhadap sikap pekerja dari pembuktian melalui uji Wilcoxon dengan membandingkan skor pretest dengan skor posttest pekerja dimana hasil $p$ value yang didapatkan sebesar 0,049 pada alpha 5\% atau taraf signifikansi sebesar 0,05 yang mana mengartikan bahwa terdapat perbedaan yang signifikan pada sikap pekerja pencetakan plastik.

Hasil Penelitian Mahmoodabad dkk (2008) tentang pengaruh edukasi kesehatan terhadap pengetahuan sikap dan tindakan siswa terhadap Brucellosis menghasilkan peningkatan sikap dengan nilai signifikansi $p<0,001$, yang berarti ada pengaruh peningkatan sikap siswa setelah pendidikan kesehatan.

Penelitian Sam dkk (2008) di wilayah Udupi, India Selatan mengenai pemberian pendidikan penanganan

keamanan pestisida terhadap pengetahuan, sikap dan tindakan dalam keselamatan bekerja menggunakan pestisida juga menunjukan adanya pengaruh pendidikan terhadap sikap dengan $p$ value yang didapatkan $<0,001$, dimana terdapat peningkatan pengetahuan, sikap dan tindakan dalam keselamatan bekerja pada penangan pestisida.

Selain itu penelitian Panggabean (2016) menunjukan hasil pada sikap petani jeruk sebelum diberikan penyuluhan memiliki sikap positif pada kelompok perlakuan $(13,3 \%)$ dan kelompok kontrol $(86,7 \%)$ dan memiliki sikap negatif pada kelompok perlakuan $(86,7 \%)$ dan kontrol $(13,3 \%)$, Setelah mendapat penyuluhan K3 tentang penggunaan APD, sikap petani jeruk pada kelompok perlakuan dan kontrol menjadi positif masing- masing (86,7\%)yang berarti ada perbedaan setelah diberikannya penyuluhan.

\section{Tindakan Pekerja Sebelum dan Setelah Penyuluhan}

Diketahui hasil observasi tindakan saat pretest hanya ada satu pekerja yang menggunakan sarung tangan $(7,7 \%)$ dari responden dan tidak ada pekerja yang menggunakan masker maupun helm. Nilai statistik penggunaan APD saat pretest ini diketahui nilai rata-rata dalam pekerja 
yang menggunakan APD hanya sebesar 0,08 .

Setelah diberikan penyuluhan, dilakukan observasi pertama pada dua hari setelahnya, dimana terdapat peningkatan jumlah penggunaan sarung tangan dan masker pada pekerja. Diketahui sembilan (90\% )dari 10 responden yang diamati menggunakan sarung tangan karet yang sesuai dengan bahaya dari bahan plastik, dikarenakan terdapat tiga responden yang tidak masuk bekerja. Penggunaan masker didapatkan dua responden (20\% yang menggunakan masker dari seluruh responden yang diamati. Tidak terjadi perubahan tindakan penggunaan helm pada pekerja, hal ini dikarenakan tidak tersedianya sarana untuk pekerja berperilaku. Menurut Notoatmodjo (2012) tindakan dapat tercipta ketika faktor lain yang mendukung yaitu

tersedianya fasilitas dan sarana prasarana. Hal yang sama dalam penggunaan helm juga terjadi pada posttest kedua dan ketiga.

Satu responden yang tidak menggunakan sarung tangan dapat dikarenakan faktor kenyamanan dalam menggunakan APD. Menurut Ridley (2008), mengatakan bahwa salah satu syarat APD adalah nyaman untuk digunakan bagi penggunanya. Sehingga ketika dilakukan observasi pertama diketahui ada satu responden yang tidak menggunakan APD sarung tangan karet. Sama halnya dengan sarung tangan,

delapan responden yang tidak menggunakan masker juga dapat dikarenakan ketidaknyamanan dalam menggunakan APD tersebut.

Observasi kedua yang dilakukan

empat hari setelah penyuluhan diberikan, menunjukan bahwa 12 dari 12 $(100 \%)$ responden yang diamati menggunakan sarung tangan kain, sementara satu dari seluruh responden yang seharusnya diteliti tidak masuk bekerja pada hari tersebut. Penggunaan masker sendiri tidak terjadi perubahan dari observasi pertama yaitu hanya 2 responden $(16,6 \%)$.
Pada Observasi ketiga, enam hari setelah pemberian penyuluhan diketahui ada 12 responden yang masuk, dan ditemukan yang menggunakan sarung tangan ketika bekerja adalah delapan responden $(80 \%)$ dari 10 responden yang menjadi kriteria pengamatan, dikarenakan dua responden tidak sedang menggunakan mesin, tetapi dalam kondisi memperbaiki mesin sehingga tidak menjadi subjek pengamatan peneliti. Dua dari responden yang menjadi pengamatan diketahui tidak menggunakan sarung tangan, hal ini bisa dikarenakan merasakan kesulitan ketika bekerja serta kenyamanan pengguna dan sementara itu satu responden tidak masuk bekerja. Penggunaan masker dari pekerja tidak ditemukan pada observasi ketiga yang mana pada sebelumnya terdapat dua responden menggunakanya, hal ini disebakan satu dari responden tersebut tidak masuk bekerja dan satu responden sedang memperbaiki mesin ketika dilakukan observasi hari ketiga, sementara sisanya dikarenakan alasan yang sama pada saat posttest pertama dan kedua yaitu merasa tidak nyaman menggunakan masker.

Secara keseluruhan dari observasi pertama sampai ketiga rata-

rata responden yang bekerja menggunakan APD setelah diberikan penyuluhan memiliki nilai rata-rata di atas dari nilai rata-rata saat pretest. Berdasarkan peningkatan nilai rata-rata tersebut maka dapat diketahui bahwa terjadi perbedaan tindakan pekerja dalam menggunakan APD ketika bekerja menggunakan mesin injeksi palstik manual.

\section{Pengaruh Penyuluhan Terhadap PeningkatanPerilaku Penggunaan APD Pekerja}

Menurut Notoatmodjo (2010) upaya intervensi terhadap faktor perilaku dapat dilakukan melalui dua pendekatan, yaitu pendidikan atau paksaan/tekanan, dan pendekatan pendidikan adalah yang paling tepat sebagai upaya untuk memecahkan 
masalah kesehatan masyarakat melalui faktor perilaku. Sementara itu penyuluhan kesehatan diartikan sebagai kegiatan pendidikan kesehatan yang dilakukan dengan cara menyebarluaskan pesan dan menanamkan keyakinan, (Azwar, 1983 dalam Maulana, 2009).

Penyuluhan di prediksi dapat merubah perilaku pekerja dalam menggunakan APD ketika menggunakan mesin injeksi plastik

manual yang sebelumnya tidak menggunakan APD sampai terjadi peningkatan perilaku pekerja yang menggunakan APD. Penyuluhan yang telah disampaikan oleh penyuluh sesuai dengan fungsi penyuluhan yang dijelaskan oleh Samsudin (1977) dalam Suprapto dan Fahrianoor (2004) yang mengatakan bahwa penyuluhan berfungsi sebagai penghubung yang menjabarkan proses penyampaian ilmu dan teknologi dari sumbernya kepada masyarakat yang membutuhkanya.

Selama proses penyuluhan, dilakukan dua bentuk metode penyuluhan yaitu metode satu arah dan metode dua arah dengan media elektronik berupa proyektor. Metode satu arah terjadi ketika penyuluh menyampaikan materi kepada responden dengan media slide dan pemutaran video mengenai jenis-jenis APD dan kecelakaan kerja, dan metode dua arah terjadi ketika sesi tanya jawab dilaksanakan antar peneliti, penyuluh dengan responden. Saat pelaksanaan penyuluhan semua berjalan kondusif, hanya terlihat satu responden yang kurang menyimak penyuluhan dengan serius karena kurang konsentrasi terhadap materi penyuluhan, selain itu terkadang terjadi sedikit gangguan dari lingkungan tempat penyuluhan.

Perilaku itu sendiri menurut Bloom dalam Notoatmodjo (2010) terbagi menjadi tiga ranah/domain yaitu pengetahun, sikap dan tindakan. Sehingga dalam melihat perubahan perilaku dapat dilihat dalam tiga aspek ini. Berdasarkan pengujian pada ketiga aspek ini semuanya mengalami perubahan kearah peningkatan, baik dari melihat jumlah rata-rata atau berdasarkan uji statistik Wilcoxon untuk aspek pengetahuan dan sikapsertaberdasarkan data observasi cheklist pada perubahan tindakan.

Berdasarkan respon terhadap stimulus dari teori Skinner yang dikutip Notoatmodjo (2012), maka perilaku pekerja sudah terbentuk kedalam dua perilaku yaitu perilaku tertutup dan perilaku terbuka. Perilaku tertutup itu dari hasil tes pengetahuan dan kuesioner sikap pekerja yang meningkat dan perilaku terbuka yang dilihat dari observasi tindakan nyata pekerja dalam menggunakan APD.

\section{KESIMPULAN}

Berdasarkan hasil penelitian dan analisis data, diperoleh:

1. Aspek Pengetahuan, diperoleh $p$ value $0,002<0,05$. Berarti terdapat pengaruh penyuluhan terhadap peningkatan pengetahuan pekerja

2. Aspek Sikap, diperoleh $p$ value $0,049<0,05$. Berarti terdapat pengaruh penyuluhan terhadap peningkatan sikap pekerja.

3. Aspek Tindakan, diperoleh peningkatan nilai rata-rata dari 0,08 menjadi 2,53, yang berarti terdapat peningkatan tindakan pekerja dalam menggunakan APD.

Kesimpulan dari penelitian ini yaitu terdapat perbedaan perilaku penggunaan APD pada pekerja di CV. Rangros Plastik Kota Malang setelah diberikan penyuluhan tentang penggunaan APD.

\section{SARAN}

Adapun saran yang diberikan adalah sebagai berikut:

\section{Pekerja Pencetakan Plastik Pekerja} diharapkan mampu

menjaga perilaku bekerja dengan menggunakan Alat Pelindung Diri (APD), menjaga perilaku bekerja dengan selamat dan sehat, saling mengingatakan untuk berperilaku aman ketika bekerja sehingga dapat mencapai produktifitas perusahaan setinggitingginya dengan meminimalisir 
kecelakaan dan penyakit akibat kerja serendah-rendahnya.

\section{Pemilik Usaha}

Supaya mampu memberikan pengawasan yang ketat terhadap

karyawan yang dalam proses pekerjaanya memiliki risiko bahaya, menyediakan Alat Pelindung Diri (APD) yang sesuai secara berkala, serta mampu mendorong pekerja untuk bekerja secara selamat dan sehat.

\section{Peneliti Selanjutnya}

a) Melakukan penelitian lanjutan tentang pengaruh penyuluhan terhadap peningkatan perilaku penggunaan APD dengan membandingkannya pada kelompok kontrol

b) Melakukan penelitian dengan membandingkan media yang paling efektif untuk merubah perilaku

c) Melakukan penelitian dengan intervensi pendidikan kesehatan yang berbeda terhadap peningkatan perilaku penggunaan Alat Pelindung Diri (APD).

\section{DAFTAR RUJUKAN}

Annishia, FB. 2011. Analisis Perilaku Tidak Aman Pekerja Konstruksi PT. PP (Persero) DI Proyek Pembangunan Tiffany Apartemen Jakarta Selatan 2011. Skripsi. Jakarta:FKIK UIN Syarif Hidayatullah.

Azwar. 2013. Sikap Manusia : Teori dan Pengukuranya. Yogyakarta: Pustaka Pelajar.

Fitriani, S. 2011. Promosi Kesehatan. Yogyakarta: Graha Ilmu.

Gunaraharja, MH. 2015. Usulan Perbaikan Sistem Kerja Proses Moulding Injection dengan

Pendekatan Lean

Manufacturing di PT Tradisi

Manufacturing Industri

Karawang Barat.Skripsi.

Bandung: FT Universitas

Widyatama.
Hameed., dkk.2012. An Intervention study to evaluate compliance with personal protective equipment among workers at tekxtile industry.Journal of American Science, 8(7) hal 117121 ISSN 1818-4952.

Mahmoodabad., dkk. 2008. The Effect of Health Education on Knowledge, Attitude and Practice (KAP) of High School Students' Towards Brucellosis in Yazd.World Applied Sciences Journal, 5 (4) hal 522-524.

Maulana, H. 2009. Promosi Kesehatan. Jakarta: EGC.

Mostafa, NS., Momen, M. 2014. Occupational Health and Safety Training: Knowledge, Attitude and Practice Among Technical Education Students.Egyptian Journal of Occupational Medicine, 38(2) hal 153-165.

Notoatmodjo, S. 2012. Promosi Kesehatan dan Perilaku Kesehatan. Jakarta: Rineka Cipta.

Notoatmodjo, S. 2010. Promosi Kesehatan: Teori dan Aplikasi. Jakarta: Rineka Cipta.

OSHA (Occupational Safety and Health Administration). 2005. Personal Protective Equipment. (Online), (www.osha.gov) diakses 11 Oktober 2016.

Panggabean, PK. 2016. Pengaruh Penyuluhan K3 Tentang APD Terhadap Pengetahuan, Sikap Petani Jeruk Dalam Penggunaan APD di Desa Suka Sipilihen Kabupaten Karo Tahun 2016. Skripsi. Medan: FKM USU.

Pratama, RK. 2013.Pengaruh Pendidikan Kesehatan Terhadap 
Perubahan Pengetahuan, Sikap

dan Perilaku Tentang

Kebiasaan Berperilaku Hidup

Bersih dan Sehat Siswa SDN 1

Mandong.Skripsi. FIK

Universitas Muhammadiyah

Surakarta.

Sam, KG., dkk. 2008. Effectiveness of

an educational program to promote pesticide safety among pesticide handlers of South India.International Archives of Occupational and

Environmental Health, 81 hal 787-795 e-ISSN 1432-1246.

Santrock. 2008. Lifespan Development Jilid 1. Jakarta: Erlangga

Solichin., dkk. 2014. Dasar-Dasar Keselamatan dan Kesehatan Kerja.Malang: Universitas Negeri Malang.

Suprapto,T., Fahrianoor. 2004. Komunikasi Penyuluhan Dalam Teori dan Praktek. Yogyakarta: Arti Bumi Intaran. 